\title{
Current and future predicting potential areas of Oxytenanthera abyssinica (A. Richard) using MaxEnt model under climate change in Northern Ethiopia
}

Yikunoamlak Gebrewahid ${ }^{1 *}$ (D, Selemawi Abrehe², Esayas Meresa', Gebru Eyasu', Kiros Abay ${ }^{5}$, Gebrehiwot Gebreab ${ }^{3}$, Kiros Kidanemariam³ ${ }^{3}$ Gezu Adissu' ${ }^{3}$, Gebrekidan Abreha ${ }^{4}$ and Girmay Darcha ${ }^{1}$

\begin{abstract}
Introduction: Climate change will either improve, reduce, or shift its appropriate climatic habitat of a particular species, which could result in shifts from its geographical range. Predicting the potential distribution through MaxEnt modeling has been developed as an appropriate tool for assessing habitat distribution and resource conservation to protect bamboo species.

Methods: Our objective is to model the current and future distribution of Oxytenanthera abyssinica (A. Richard) based on three representative concentration pathways (RCP) (RCP2.6, RCP4.5, and RCP8.5) for 2050s and 2070s using a maximum entropy model (MaxEnt) in Northern Ethiopia. For modeling procedure, 77 occurrence records and 11 variables were retained to simulate the current and future distributions of Oxytenanthera abyssinica in Northern Ethiopia. To evaluate the performance of the model, the area under the receiver operating characteristic (ROC) curve (AUC) was used.

Results: All of the AUCS (area under curves) were greater than 0.900, thereby placing these models in the "excellent" category. The jackknife test also showed that precipitation of the coldest quarter (Bio19) and precipitation of the warmest quarter (Bio18) contributed $66.8 \%$ and $54.7 \%$ to the model. From the area of current distribution, $1367.51 \mathrm{~km}^{2}$ (2.52\%), $7226.28 \mathrm{~km}^{2}$ (13.29\%), and $5377.26 \mathrm{~km}^{2}$ (9.89\%) of the study area were recognized as high, good, and moderate potential habitats of Oxytenanthera abyssinica in Northern Ethiopia, and the high potential area was mainly concentrated in Tanqua Abergele (0.70\%), Kola Temben (0.65\%), Tselemti $(0.60 \%)$, and Tsegede (0.31\%). Kafta Humera was also the largest good potential area, which accounts for $2.75 \%$. Compared to the current distribution, the total area of the high potential regions and good potential regions for Oxytenanthera abyssinica under the three RCPs (RCP2.6, RCP4.5, and RCP8.5) would increase in the 2050s and 2070s. However, the total area of the least potential regions under the three RCPs (RCP2.6, RCP4.5, and RCP8.5) in 2050s and 2070s would decrease.

Conclusion: This study can provide vital information for the protection, management, and sustainable use of Oxytenanthera abyssinica, the resource to address the global climate challenges.
\end{abstract}

Keywords: Oxytenanthera abyssinica, MaxEnt model, Climate change

\footnotetext{
*Correspondence: yikuno22@gmail.com; yikuno22@yahoo.com

${ }^{1}$ Mekelle Agricultural Research Center (MARC), Tigray Agricultural Research

Institute (TARI), P.O. Box 256, Tigray, Ethiopia

Full list of author information is available at the end of the article
} 


\section{Introduction}

Bamboo plants grow in the tropical and temperate regions, with predominance in Southeast Asia (Banik 1985). There are more than 1500 species of bamboo in the globe (Ohrnberger 1999), covering more than 14 million ha of land. About 40 of these species occur naturally or have been introduced in Africa, with an area of more than 1.5 million ha of land (Kigomo 1988), and two of these species are indigenous to Ethiopia: Oxytenanthera abyssinica (A. Richard) (lowland bamboo) and Arundinaria alpina (K. Schum.) (highland bamboo). The natural forest of bamboo in Ethiopian covers around 1 million ha, about $7 \%$ of the total forest cover of bamboo in the world and $67 \%$ of African bamboo forest area (Embaye 2003). About 130,000 ha of Arundinaria alpina and about 850,000 ha of Oxytenanthera abyssinica are found scattered in the northern, south, south-west, and central parts of Ethiopia. They were in natural forest conditions that were more or less pure, completely distributed. However, for agricultural land expansion, they are being cleaned at an accelerating rate, burned to promote more tender grass growth for grazing and destroy supposedly damaging insects. Large plantations of coffee and tea and metropolitan expansion also emerge as actual and potential threats (Embaye 2003). Sustained availability and utilization can be ensured by proactive bamboo cultivation (Shanmughavel and Francis 1995).

Bamboo is important for socio-economic growth potential (Baghel et al. 1998, Perez et al. 1999) and environmental protection (Bystriakova et al. 2004). It can be also used as an agroforestry species, for house building, for animal feed, for human consumption (Christanty et al. 1997), for soil fertility maintenance (Gebrewahid et al. 2019), as a source of cash revenue, and as a medicine for the treatment of many disease types (Yuming et al. 2004). The forest of bamboo is also a source of wood for furnishings, pulp, particleboard, and bioenergy (Embaye 2000).

In order to know the overall distribution trends and to protect Oxytenanthera abyssinica species, it is important to examine important environmental variables affecting their natural distribution. This data can then be used to determine appropriate places to protect the habitat. Our objective was therefore to define the potential distribution of Oxytenanthera abyssinica and environmental constraints using MaxEnt in Northern Ethiopia. This research concentrated primarily on the following strategy: (1) Oxytenanthera abyssinica's dominant environmental factors were selected to develop a model, (2) identification of the present potential regions for cultivation and conservation of Oxytenanthera abyssinica by current bioclimatic factors, and (3) model-based predictions were predicted for potential distributions of Oxytenanthera abyssinica under multiple future climate scenarios.

\section{Materials and methods}

\section{Study species}

Oxytenanthera abyssinica (Poaceae) is prominent in river basins and locally on the western part of the central highlands in dry and moist Kolla agroclimatic areas of Benishagul Gumuz and Western Tigray from 1200 to $1800 \mathrm{~m}$ above sea level (BekeleTesemma and Tengnäs 2007). The species is categorized to tall grass with woody culms and a height of $13 \mathrm{~m}$ (Phillips 1995), unusual for a solid stem with a diameter of up to $10 \mathrm{~cm}$ at the base (BekeleTesemma and Tengnäs, 2007, Bein et al. 1996). The annual rainfall ranges from approximately 700 to $1000 \mathrm{~mm}$, concentrated over a range of 3 to 4 months at an average annual temperature above 30 ${ }^{\circ} \mathrm{C}$ (UNIDO 2009). The species adapts widely to low fertile soils and provides to desert regions as a buffer area (UNIDO 2009). This species flowering happens approximately every 7 years, and then, the clumps disappear but grow up from the rhizomes 1 year later (Bekele-Tesemma and Tengnäs 2007).

\section{Species occurrence and environmental data}

A total of 77 locations with Oxytenanthera abyssinica occurrence were recorded during 2018-2019 using the Global Positioning System (GPS) and field surveys. All present data have been entered into Microsoft Excel and saved as format "CSV." The most significant factors in identifying environmental niches of species are bioclimatic factors. The 19 bioclimatic variables resulted from the long-term recording of monthly rainfall and temperature value (1950-2000) (Hijmans et al. 2005). The data had a spatial resolution of approximately $1 \mathrm{~km}^{2}(30 \mathrm{~s})$ and was downloaded from the WorldClim dataset (www. worldclim.org). General Circulation Model (GCM) Representative Climate Community Climate System Model version 4 (CCSM4) was used to estimate the impacts of the future climate on Oxytenanthera abysinica. To test Oxytenanthera abyssinica habitat suitability ranges in the 2050s (2041-2060) and 2070s (2061-2080), RCP2.6 (the minimum scenario for GHG emissions), RCP4.5 (the intermediate scenario for GHG emissions), and RCP8.5 (the highest scenario for GHG emissions) were used. In total, 19 bioclimatic variables (Bio1-Bio19) and 2 topographical factors (slope and altitude) were used to identify factors with the biggest influences on distribution of 
Table 1 Environmental variables used in species distribution modeling process

\begin{tabular}{|c|c|c|}
\hline Variable code & Variable type & Unit \\
\hline Bio1 & Annual mean temperature & ${ }^{\circ} \mathrm{C}$ \\
\hline $\mathrm{Bio} 2$ & Mean diurnal range (max temp - min temp) (monthly average) & ${ }^{\circ} \mathrm{C}$ \\
\hline Bio3 & Isothermality $(\mathrm{Bio} 1 / \mathrm{Bio} 7) \times 100$ & ${ }^{\circ} \mathrm{C}$ \\
\hline Bio4 & Temperature seasonality (co-efficient of variation) & ${ }^{\circ} \mathrm{C}$ \\
\hline Bio5 & Max temperature of warmest period & ${ }^{\circ} \mathrm{C}$ \\
\hline Bio6 & Min temperature of coldest period & ${ }^{\circ} \mathrm{C}$ \\
\hline Bio7 & Temperature annual range (Bio5 - Bio6) & ${ }^{\circ} \mathrm{C}$ \\
\hline Bio8 & Mean temperature of wettest quarter & ${ }^{\circ} \mathrm{C}$ \\
\hline Bio9 & Mean temperature of driest quarter & ${ }^{\circ} \mathrm{C}$ \\
\hline Bio10 & Mean temperature of warmest quarter & ${ }^{\circ} \mathrm{C}$ \\
\hline Bio11 & Mean temperature of coldest quarter & ${ }^{\circ} \mathrm{C}$ \\
\hline Bio12 & Annual precipitation & $\mathrm{mm}$ \\
\hline Bio13 & Precipitation of wettest period & $\mathrm{mm}$ \\
\hline Bio14 & Precipitation of driest period & $\mathrm{mm}$ \\
\hline Bio15 & Precipitation seasonality (co-efficient of variation) & $\mathrm{mm}$ \\
\hline Bio16 & Precipitation of wettest quarter & $\mathrm{mm}$ \\
\hline Bio17 & Precipitation of driest quarter & $\mathrm{mm}$ \\
\hline Bio18 & Precipitation of warmest quarter & $\mathrm{mm}$ \\
\hline Bio19 & Precipitation of coldest quarter & $\mathrm{mm}$ \\
\hline Elevation & Elevation & $\mathrm{m}$ \\
\hline Slope & Slope & $\%$ \\
\hline
\end{tabular}

Oxytenanthera abyssinica (Table 1). Using ArcGIS software version 10.3, the Advanced Space-borne Thermal Emission and Reflection Radiometer Digital Elevation Model (Aster DEM) information was used to produce slope maps and the Aster DEM variable with $30 \mathrm{~m}$ spatial resolution was downloaded from Geospatial Data Cloud (http://www.gscloud.cn/). The Pearson correlation coefficient was used to account for multicollinearity between the bioclimatic (Bio1Bio19) and topographic (elevation and slope) variable factors (Elith et al. 2006, Stohlgren et al. 2011). In order to determine and exclude extremely correlated variables, removing all the variables with correlation coefficient $<0.8$ (Elith et al. 2010) was used as a cutoff limit to minimize the effect of multicollinearity and model overfitting (Wang et al. 2018) and maintain 11 variables below this threshold to simulate Oxytenanthera abyssinica current and future outcomes in Northern Ethiopia (Table 2). The contribution percentage and permutation importance are significant factors that assess the environmental variable importance. Permutation importance rather than the path is used in an individual run-up to the final results of the model and therefore is easier for assessing the significance of a particular variable (Songer et al. 2012).

\section{Data analysis}

MaxEnt is now a popular species distribution modeling (SDM) instrument used to predict species distribution (Fourcade et al. 2014) and classified as a background activity technique (presence information only). It uses the maximum entropy algorithm and incidence of species to estimate the likelihood of incidence of species in unidentified event regions (Phillips 2006). This technique is not susceptible to sample size and in comparison to environmental variables can produce species response curves (Khanum et al. 2013). Independent data collected from sites other than those used to train the model are essential to evaluate the predictive performance of the model. Therefore, species occurrence information for model calibration was divided into a training set (75\% of total occurrence records) and test set (25\% of total occurrence records) for design assessment. All environmental factors have been converted to the same pixel size $(30 \mathrm{~m})$ and projection (meter) ASCII raster grids format. The modeling process is 


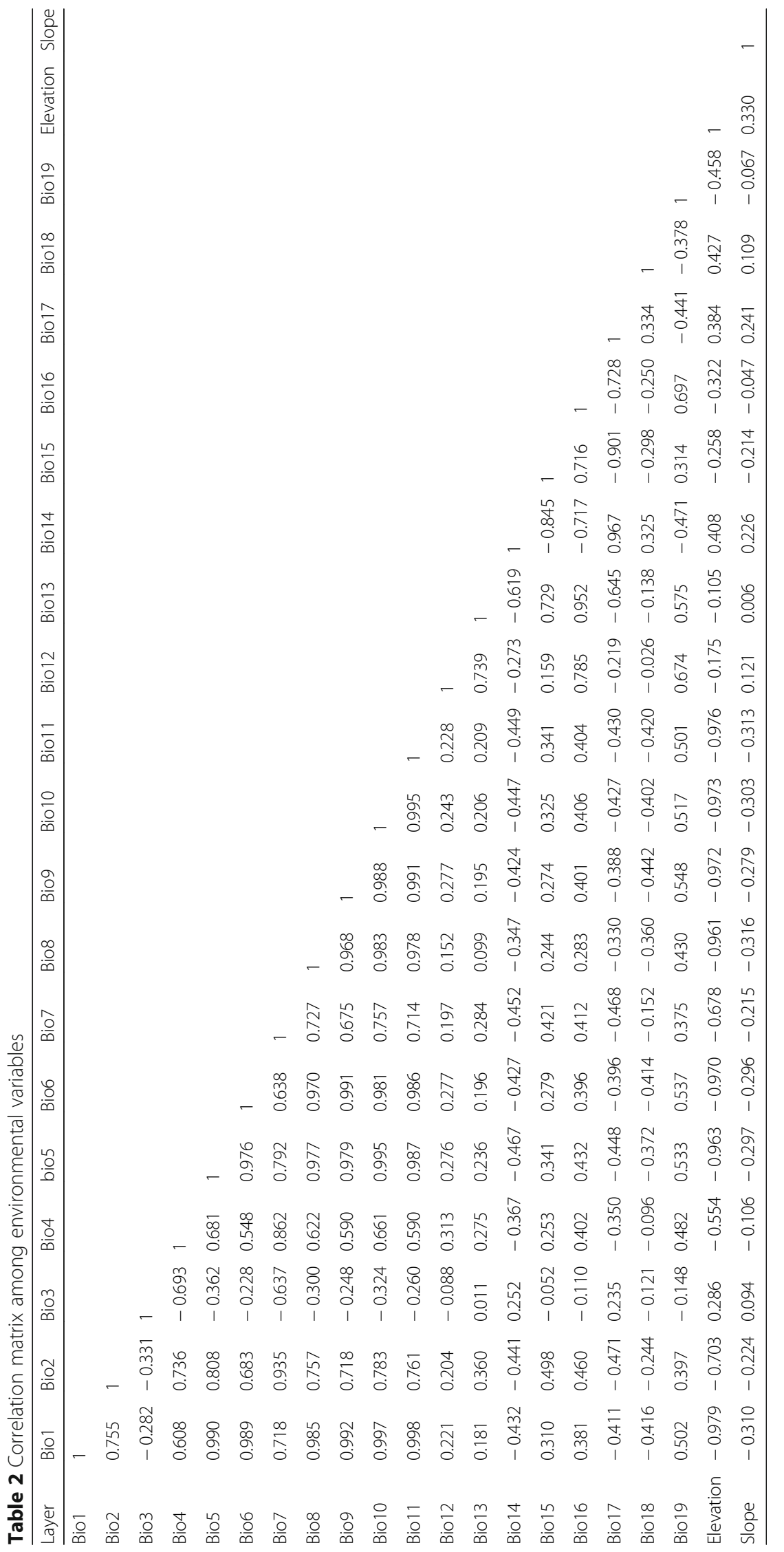


chosen for linear and quadratic features. The model generated was evaluated by calculating the AUC of the receiver operating characteristic (ROC) plot (Phillips 2006). The AUC is a model performance measure and ranges between 0 and 1 , and perfect discrimination shows a value of 1 (Fielding and Bell 1997). The AUC was an efficient autonomous threshold index capable of evaluating the ability of a model to discriminate presence from absence. AUC scores could be divided into five categories (Swets 1988). AUC $<0.5$ describes models that are less than chance and rarely occur in reality. An AUC of 0.5 is a pure guess. Model performance is classified as failing (0.5 to 0.6$)$, bad (0.6 to 0.7 ), reasonable ( 0.7 to $0.8)$, good (0.8 to 0.9$)$, or great (0.9 to 1 ) (Swets 1988). The jackknife test (systematically excluding each variable) was used to assess the dominant environmental variables that determined the species potential distribution (Yang et al. 2013). Species response curves were created to investigate the relationship between target species habitat suitability and environmental factors. The prospective species distribution chart generated had values ranging from 0 to 1 . These values have been grouped into four groups: high potential $(>0.6)$, good potential $(0.4-$ $0.6)$, moderate potential $(0.2-0.4)$, and low potential $(<0.2)$ (Yang et al. 2013).

\section{Results}

Evaluations of the model and its importance to variables under current climatic condition

The calibration of the model for Oxytenanthera abyssinica was satisfactory (AUCmean $=0.903$, Fig.
1). The findings indicated that Oxytenanthera abyssinica current distribution characterized by the selected variables is excellent. The test of the jackknife indicates the distribution of Oxytenanthera abyssinica was mainly influenced by the coldest quarter precipitation (Bio19) and warmest quarter precipitation (Bio18) and contributed $42.0 \%$ and $24.8 \%$ to the MaxEnt model (Fig. 2). The species habitat model was also collectively contributed by nine other layers of environmental factors of $32.3 \%$ and two topographic factors of $6.5 \%$ (Fig. 2 and Table 3). In consideration of the permutation importance, precipitation of the coldest quarter (Bio19) had the highest impact on the habitat model and contributed $33.3 \%$, while precipitation of the warmest quarter (Bio18) and isothermality (Bio3) together contributed 32.9\% (Table 3). Species response curve depicts the relationship between environmental variables and the probability of species incidence; they show biological tolerances for target species and habitat preferences. Based on the species response curves acquired, Oxytenanthera abyssinica prefers the coldest quarter precipitation ranges from 700 to $780 \mathrm{~mm}$, warmest quarter precipitation ranges from 10 to $45 \mathrm{~mm}$, isothermal ranges from 76 to $77{ }^{\circ} \mathrm{C}$, driest quarter precipitation ranges from 80 to 150 $\mathrm{mm}$, and seasonal precipitation ranges from 145 to $155 \mathrm{~mm}$ (Fig. 3).

\section{Current potential distribution of Oxytenanthera abyssinica}

Species distribution maps indicated that 2.52\%, $13.29 \%$, and $9.89 \%$ of the study area respectively

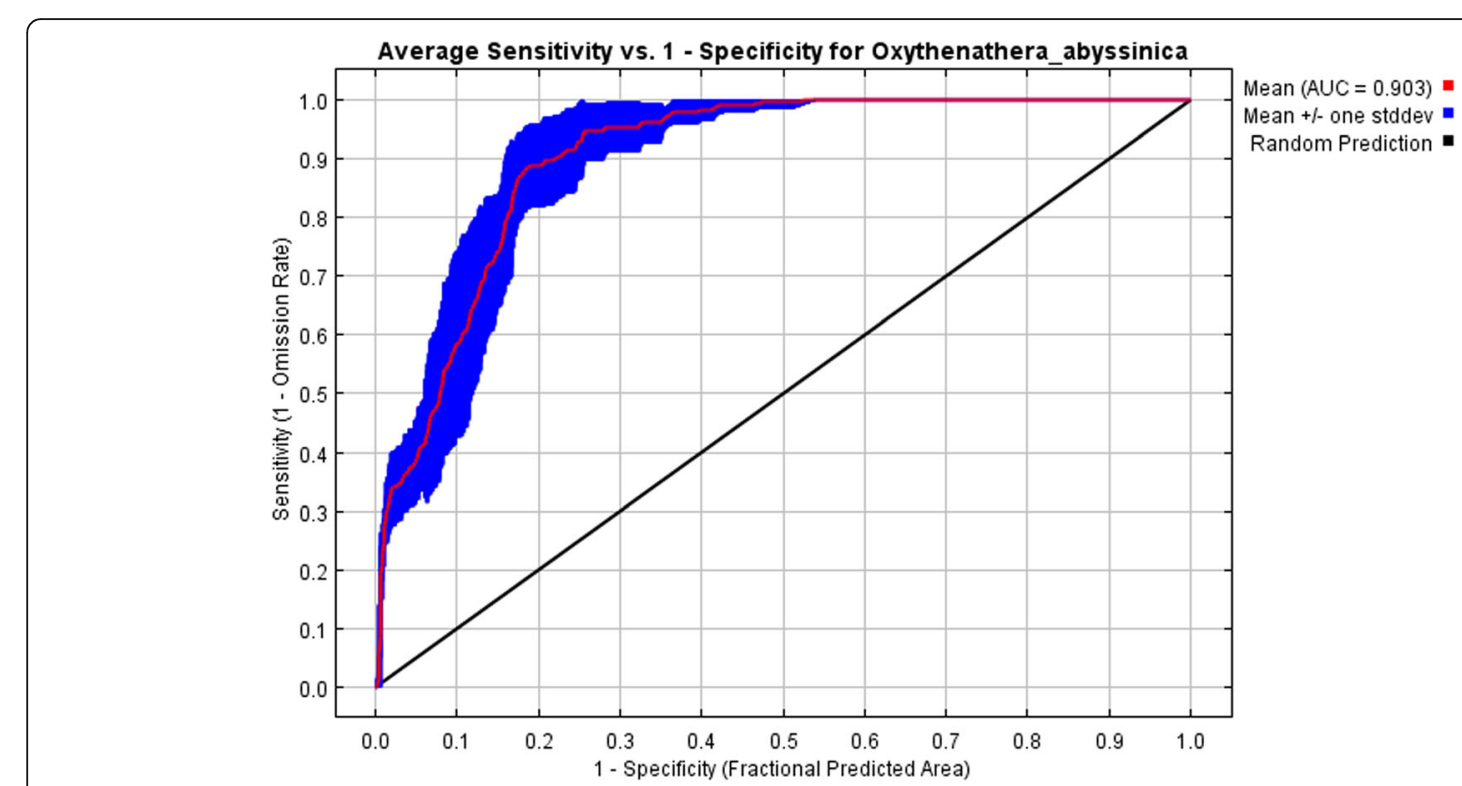

Fig. 1 ROC curve and AUC value under the current period (10 replicated runs). The current period was from 1950 to 2000 


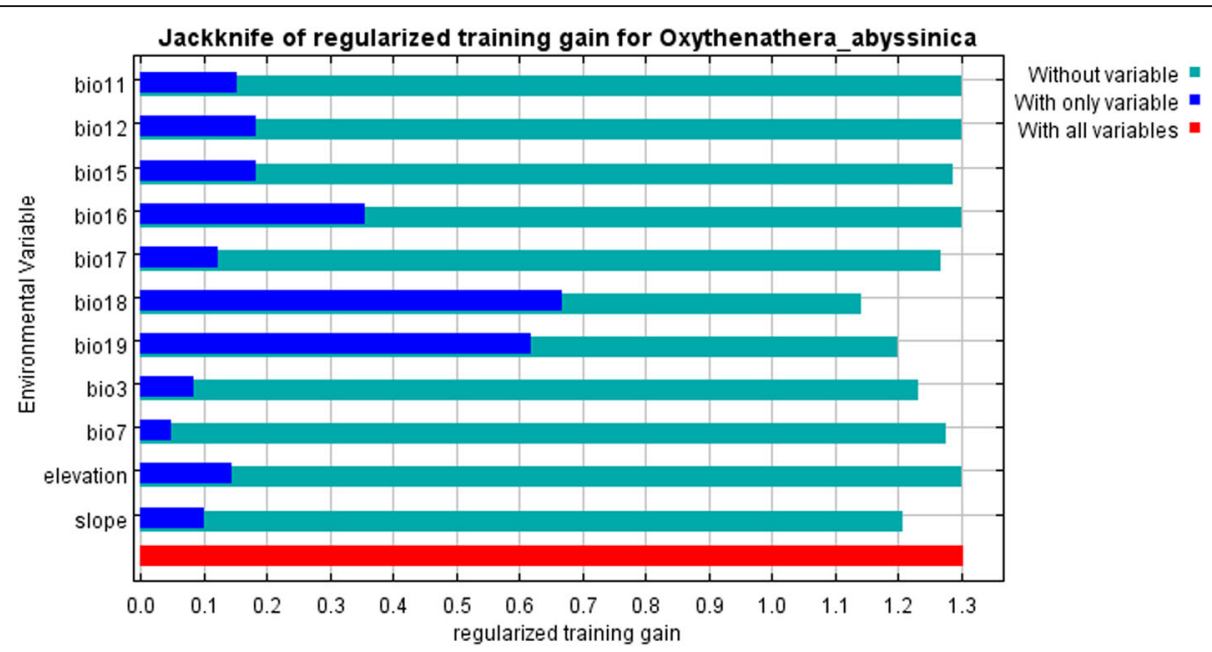

Fig. 2 Relative predictive power of different environmental variables based on the jackknife of regularized training gain in MaxEnt models for O. abyssinica

were identified as high, good, and moderate potential habitats of Oxytenanthera abyssinica in Northern Ethiopia (Table 4 and Fig. 4). Apparently, mainly in Central and Northwestern Tigray were identified as the high distribution areas. In addition, Oxytenanthera abyssinica's ecologically good distribution areas were mainly situated in lowland areas of West and Northwest of Tigray. The average of Oxytenanthera abyssinica's high distribution region was estimated $1367.51 \mathrm{~km}^{2}(2.52 \%)$, while the good and moderate distributed regions were about 7226.28 (13.29\%) and $5377.26 \mathrm{~km}^{2}$ (9.89\%).
Model evaluations and its importance to variables under different scenarios

The AUC values for 2050s RCP 2.6, 2070s RCP 2.6, 2050s RCP 4.5, 2070s RCP 4.5, 2050s RCP 8.5, and 2070s RCP 8.5 were respectively $0.887,0.892,0.915$, 913, 0.908, and 0.924, indicating that the expected findings were very accurate. By selecting the option "Do jackknife to measure important variable" (Jackknife), the percentage contribution values of each ecological factor (Table 3) were obtained, which were defined only heuristically and depended on the specific path used by the MaxEnt code to obtain the

Table 3 Estimates of relative contributions and permutation importance of the predictor environmental variables to the MaxEnt model

\begin{tabular}{|c|c|c|c|c|c|c|c|c|c|c|c|c|c|}
\hline Time & RCPs & Variable & Bio3 & Bio7 & Bio11 & Bio12 & Bio15 & Bio16 & Bio17 & Bio18 & Bio19 & Elevation & Slope \\
\hline \multirow[t]{2}{*}{ Present time } & & Percent contribution & 11.1 & 2.3 & 0.8 & 0.1 & 5.3 & 0.1 & 7.0 & 24.8 & 42.0 & 0.1 & 6.4 \\
\hline & & Permutation importance & 11.5 & 6.2 & 0.6 & 3.1 & 8.3 & 2.3 & 8.8 & 21.4 & 33.3 & 0.7 & 3.8 \\
\hline \multirow[t]{6}{*}{2050} & 2.6 & Percent contribution & 11.8 & 2.2 & 2.4 & 2.0 & 6.1 & 4.8 & 5.2 & 3.0 & 50.6 & 2.5 & 9.4 \\
\hline & & Permutation importance & 3.9 & 2.2 & 8.3 & 7.1 & 8.3 & 34.7 & 13.7 & 3.2 & 4.8 & 11.8 & 1.9 \\
\hline & 4.5 & Percent contribution & 18.6 & 5.8 & 1.9 & - & 5.4 & 10.0 & 4.6 & 3.6 & 40.1 & 2.4 & 7.4 \\
\hline & & Permutation importance & 8.0 & 1.9 & 6.5 & - & 6.1 & 30.6 & 10.2 & 17 & 7.6 & 7.8 & 4.2 \\
\hline & 8.5 & Percent contribution & 10.1 & 1.1 & 4.1 & - & 6.9 & 14.4 & 5.8 & 4.7 & 38.7 & 5.7 & 8.3 \\
\hline & & Permutation importance & 1.0 & 1.6 & 12.3 & - & 9.8 & 39.0 & 13.7 & 3.9 & 7.2 & 9.0 & 2.5 \\
\hline \multirow[t]{6}{*}{2070} & 2.6 & Percent contribution & 7.0 & 1.5 & 1.2 & 1.9 & 7.6 & 7.3 & 7.9 & 12.8 & 41.6 & 3.9 & 7.4 \\
\hline & & Permutation importance & 1.3 & 2.2 & 7.6 & 14.3 & 15.6 & 18.4 & 12.1 & 7.4 & 7.4 & 10.6 & 3.2 \\
\hline & 4.5 & Percent contribution & 13.8 & 3.6 & 4.6 & 3.1 & 7.2 & 6.7 & 3.7 & 1.6 & 44.0 & 3.8 & 7.9 \\
\hline & & Permutation importance & 4.9 & 0.1 & 11.7 & 18.1 & 15.6 & 19.8 & 10.8 & 2.1 & 3.5 & 10.0 & 3.3 \\
\hline & 8.5 & Percent contribution & 7 & 0.9 & 2.3 & - & 7.5 & 14.4 & 3.1 & 0.9 & 45.2 & 9.4 & 9.3 \\
\hline & & Permutation importance & 2.5 & 0.7 & 2.8 & - & 3.8 & 46.0 & 5.6 & 3.0 & 16.1 & 15.1 & 4.6 \\
\hline
\end{tabular}



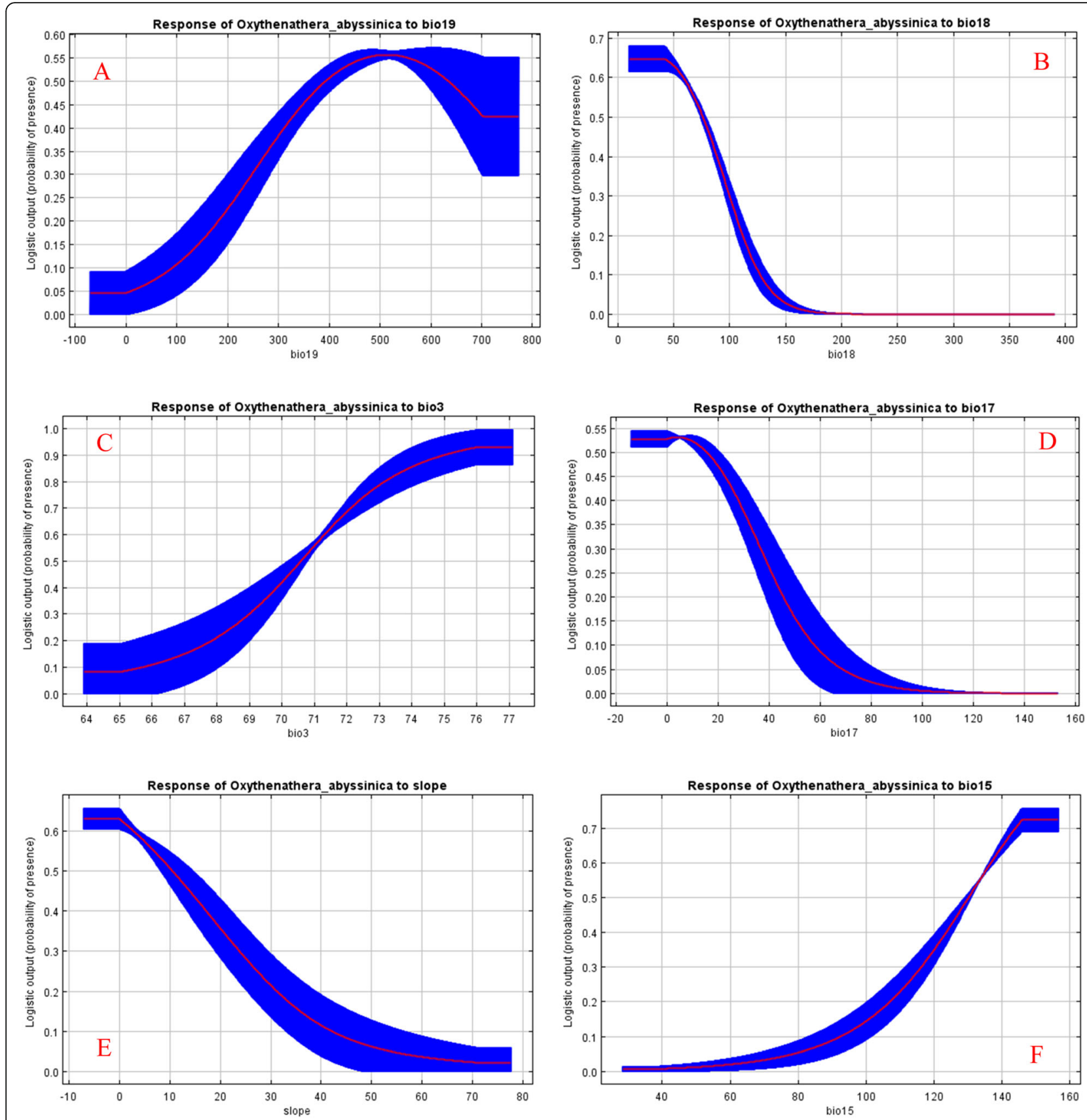

Fig. 3 O. abyssinica response curves in relation to a precipitation of coldest quarter-Bio19, b precipitation of warmest quarter-Bio18, c isothermality—Bio3, $\mathbf{d}$ precipitation of driest quarter-Bio17, e slope, and $\mathbf{f}$ precipitation seasonality-Bio15

optimal solution. The model also referred to the impact of environmental factors in determining the optimal parameters of the environment (Fig. 5). The jackknife test reveals that the distribution of Oxytenanthera abyssinica was mainly influenced by the coldest quarter precipitation (Bio19) in all predictions which contributed 50.6\%, 40.1\%, 38.7\%, 41.6\%,
$44 \%$, and $45.2 \%$ for 2050 s RCP 2.6, 2050s RCP 4.5, 2070s RCP 2.6, 2070s RCP 4.5, and 2070s RCP 8.5, respectively, to the MaxEnt model (Fig. 5). According to the species response curves obtained, Oxytenanthera abyssinica prefers precipitation coldestquartered habitats which ranges from 700 to 860 $\mathrm{mm}, 730$ to $900 \mathrm{~mm}, 650$ to $870 \mathrm{~mm}, 810$ to 910 
Table 4 Predicted potential distribution areas for O. abyssinica under current climatic conditions

\begin{tabular}{lllllllll}
\hline Number & Wereda & $\begin{array}{l}\text { Zone } \\
\text { name }\end{array}$ & $\begin{array}{l}\text { Moderate } \\
\text { potential (ha) })\end{array}$ & $\begin{array}{l}\text { Good } \\
\text { potential (ha) })\end{array}$ & $\begin{array}{l}\text { High } \\
\text { potential (ha) }\end{array}$ & $\begin{array}{l}\text { Percentage of } \\
\text { moderate potential }\end{array}$ & $\begin{array}{l}\text { Percentage of } \\
\text { good potential }\end{array}$ & $\begin{array}{l}\text { Percentage of } \\
\text { high potential }\end{array}$ \\
\hline 1 & Abiy Adi Town & Central & 14.67 & 71.73 & 2225.07 & 0.0003 & 0.0013 & 0.0409 \\
2 & Asgede Tsimbla & North Western & $58,997.61$ & $47,796.30$ & 3018.33 & 1.0854 & 0.8791 & 0.0555 \\
3 & Degua Temben & South Eastern & 482.04 & 311.94 & 1220.85 & 0.0089 & 0.0057 & 0.0225 \\
4 & Kafta Humera & Western & $150,599.16$ & $149,431.68$ & - & 2.7707 & 2.7484 & 0.0000 \\
5 & Kola Temben & Central & 9586.44 & $19,007.55$ & $35,447.04$ & 0.1764 & 0.3496 & 0.6522 \\
6 & Medebay Zana & North Western & $11,628.54$ & $22,066.11$ & 3695.76 & 0.2139 & 0.4059 & 0.0680 \\
7 & Naeder Adet & Central & $13,576.14$ & $21,789.36$ & 2888.10 & 0.2498 & 0.4008 & 0.0531 \\
8 & Saharti Samre & South Eastern & 8500.32 & 1476.09 & 534.24 & 0.1564 & 0.0271 & 0.0098 \\
9 & Tahtay Adiyabo & North Western & 582.39 & 108.18 & - & 0.0107 & 0.0020 & 0.0000 \\
10 & Tahtay Koraro & North Western & 2347.74 & 812.97 & 13.32 & 0.0432 & 0.0150 & 0.0002 \\
11 & Tahtay Maychew & Central & 2641.77 & 4532.13 & 22.68 & 0.0486 & 0.0834 & 0.0004 \\
12 & Tanqua Abergele & Central & 8953.20 & 6991.47 & $38,082.60$ & 0.1647 & 0.1286 & 0.7007 \\
13 & Tsegede & Western & $45,753.93$ & $193,899.69$ & $16,805.88$ & 0.8418 & 3.5663 & 0.3092 \\
14 & Tselemti & North Western & $68,990.31$ & $122,974.47$ & $32,595.57$ & 1.2693 & 2.2618 & 0.5997 \\
15 & Welkait & Western & $155,072.34$ & $131,358.60$ & 201.60 & 2.8530 & 2.4160 & 0.0037 \\
& Total area & & $537,726.60$ & $722,628.27$ & $136,751.04$ & 9.89 & 13.29 & 2.52 \\
\hline
\end{tabular}

$\mathrm{mm}$, and 850 to $960 \mathrm{~mm}$ for 2050s RCP 2.6, 2070s RCP 2.6, 2070s RCP 4.5, 2050s RCP 8.5, and 2070s RCP 8.5 climate projections, respectively.

\section{Future prediction potential distribution of Oxytenanthera abyssinica}

Species distribution maps revealed that in the midcentury (2050), projections of RCP 2.6, RCP 4.5, and RCP 8.5 scenarios of the study area were identified as high potential habitats for Oxytenanthera abyssinica which were $3.21 \%, 5.52 \%$, and $5.61 \%$ respectively (Table 7 and Fig. 6), and projections for high potential habitats of Oxytenanthera abysinica in the end century (2070) scenarios of RCP 2.6, RCP 4.5, and RCP 8.5 were $3.68 \%, 5.79 \%$, and $6.70 \%$, respectively. MaxEnt's average future predictions for 2050 and 2070 (CCSM4 emission scenario) revealed an increment in suitable habitats of Oxytenanthera abyssinica in lowland sites of Central, Western, Northwestern, and Western areas of Tigray (Tables 5 and 6). In the mid-century (2050), the highest potential distribution area for Oxytenanthera abyssinica was dominated in Tanqua Abergele, Tsegeda, and Tselemti area in all RCP's (Table 5), and in the end century (2070), Tanqua Abergele was the highest potential distribution area for Oxytenanthera abyssinica in all RCP's, whereas Teselemti and Asgede Tsimbla have the highest potential in RCP 2.6, Tselemti and Tsegedea have the highest potential in RCP 4.5, and Tsegede and Welkait have the highest potential in RCP 8.5 for distribution of Oxytenanthera abyssinica (Table 6). Future scenarios increase over the current distribution of Oxytenanthera abyssinica by $21.5 \%$ in $2050 \mathrm{~s}$ RCP 2.6 , $31.5 \%$ in 2070 s RCP $2.6,54.3 \%$ in 2050 s RCP 4.5 , $56.5 \%$ in 2070 s RCP $4.5,55.1 \%$ in 2050 s RCP 8.5 , and $62.4 \%$ in 2050 s RCP 8.5 (Table 7).

\section{Discussion}

\section{Oxytenanthera abyssinica habitat suitability and their} important environmental variables

Climate modeling of tree distribution has shown that future global climate change will have important effects on forest ecosystems (Hamann and Wang 2006, Wang et al. 2011). Discrepancies exist between varying climate modeling models (Cheaib et al. 2012), but the strategy still acts as a significant study tool to assess and predict future changes in the distribution of species (Iverson and McKenzie 2013). Oxytenanthera abyssinica is a threatened plant, and its population in its native areas has been steadily declining due to numerous human-induced threats, primarily habitat fragmentation and illegal harvesting (Embaye 2003). In addition, economically significant species such as Oxytenanthera abyssinica are considered as an indication of environmental integrity and play a crucial part in the restoration of Northern Ethiopia's degraded ecosystem, and hence, its 


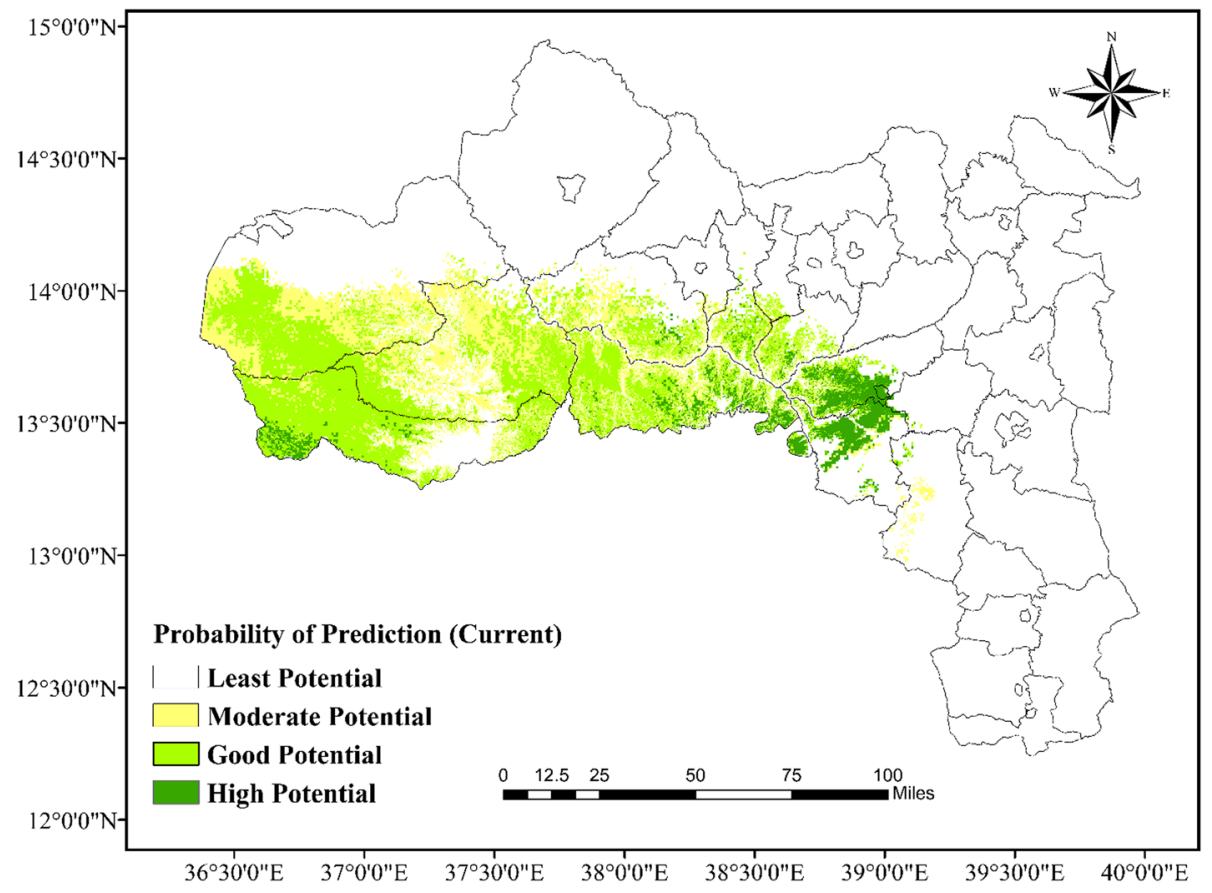

Fig. 4 Potentially suitable climatic distribution of O. abyssinica under current climate condition in Northern Ethiopia

conservation is of the highest significance in the context of Northern Ethiopia's future predicted warming climate. Research showed a more detailed survey on the suitable habitat of Oxytenanthera abyssinica in Northern Ethiopia using the MaxEnt ecological niche modeling software that will help as a significant first stage in the development of strategies and policies to manage and use this important forest tree.

Our models achieved AUC values of 0.903 which for models to be considered strong are within the acceptable range. Swets (1988), Elith (2000), and Pearce and Ferrier (2000) stated that AUC values above 0.75 might be helpful and appropriate in evaluating the performance of a niche model. After removing auto-correlated parameters (Table 1), MaxEnt stated that three factors of precipitation (Bio17, Bio18, and Bio19), slope, and one temperature (Bio3) had $91.3 \%$ more contribution to the current distribution of Oxytenanthera abyssinica (Table $3)$. The main role in determining the potential distribution habitats of Oxytenanthera abyssinica is played by precipitation and temperature (Zhong et al. 2010).

\section{Changes in the distribution of Oxytenanthera abyssinica in the future}

Future model projections from the 2050s and 2070s obtained from the IPCC climate change scenario indicated that climate change would significantly affect this species distribution, but the particular impacts will differ from one location to another. Overall, in response to global warming, the model predicted that highly and good suitable habitats would be expanded in most areas, but these more suitable habitats will effectively reduce in a few particular places. In addition, in response to the predicted climate changes, the overall locations of the most favorable habitats would significantly shift in most woredas. Global warming promotes the growth of vegetation (Cao et al. 2004, Xu et al. 2015), and a simulation of the warming climate in Northern Ethiopia's hilly area found that temperature had a positive impact on the mountain steppe by accelerating the growing season's alpine process. However, a continuous increase in temperature had an adverse impact on plants (Xu and Xue 2013). The moderate, good, and high potential of the overall landscape and areas with habitats suitable for Oxytenanthera abyssinica's survival in the RCP8.5 scenario was higher than in RCP2.6 and RCP 4.5 in both midcentury (the 2050s) and end-century (the 2070s). Therefore, an increase in temperature might be a cause shifting their habitat from the lower elevation to the higher elevation, and this leads to an increase in Oxytenanthera abyssinica's distribution in those 


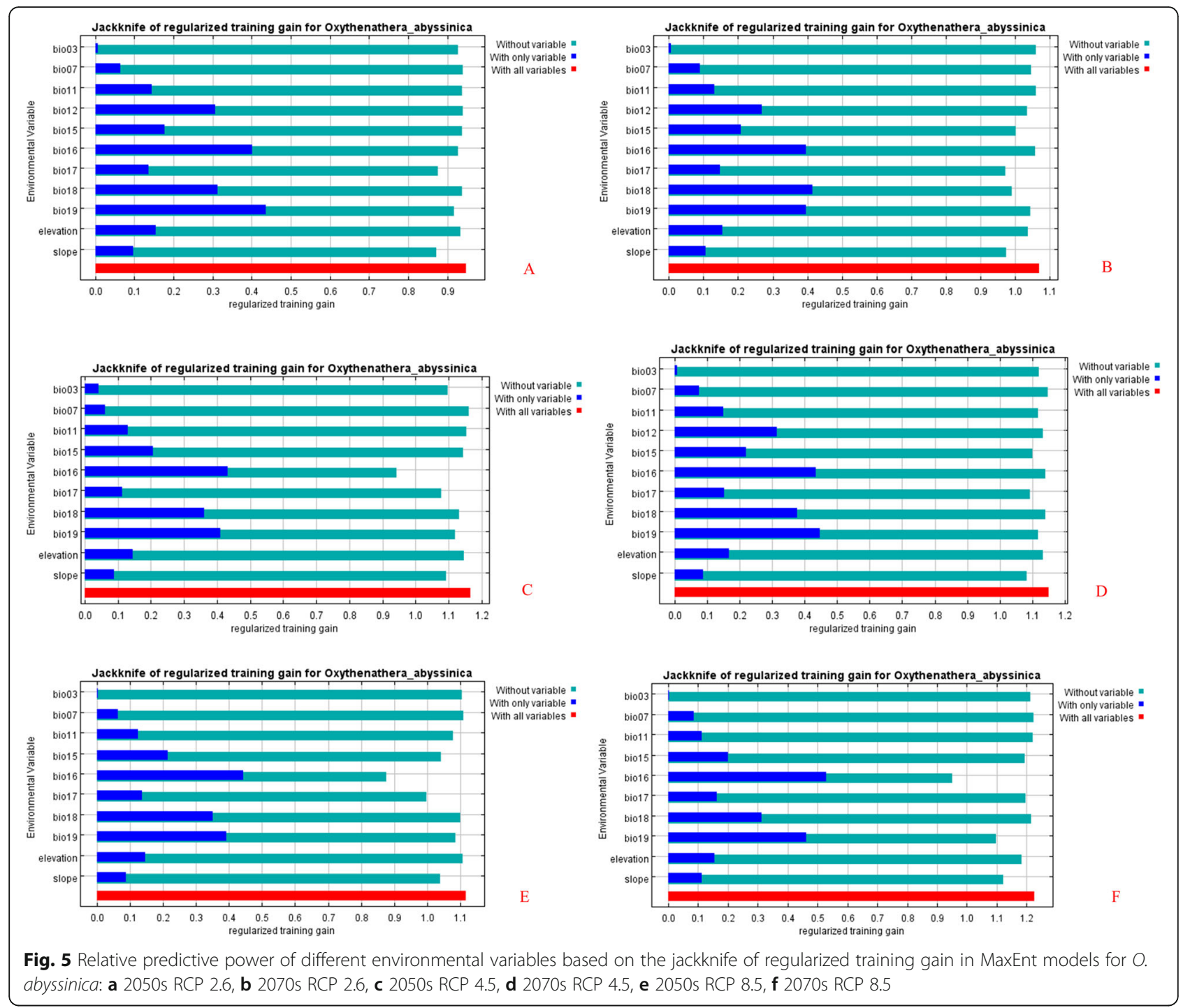

sites over time and especially towards the end of the century.

If the establishment or expansion of the current areas is not viable due to financial, political, or cultural constraints, this study suggests that in such vulnerable environmental regions, collaborative $O x y$ tenanthera abyssinica habitat conservation programs should be developed and implemented with grassroot assistance. Through some exemplary efforts, such as area closure programs, Tigray regional state is regarded as a leader in human-oriented conservation practice in the global arena. Rainfall is the main factor of Oxytenanthera abysinica distribution, and such collaborative programs aimed at soil and water conservation will increase the habitat of Oxytenanthera abysinica and support Oxytenanthera abysinica in changing potential warming impacts. This not only helps Oxytenanthera abyssinica but also other economically important species in areas that are similarly vulnerable and may lose their habitat due to such unexpected warming. An appropriate strategy in this sense could be to implement socio-ecological frameworks for landscape planning and conservation that link human beings and their socio-culture and ecological mechanisms (Virapongse et al. 2016, Lamsal et al. 2017, MartínLópez et al. 2017).

There is uncertainty in the modeling of the distribution of species, primarily due to several basic assumptions of the model and gaps in potential changes in greenhouse gases (GHG) emissions. It should be observed that while MaxEnt is efficient in modeling species habitat niche with small occurrence data and restricted ecological information, the climate factors 

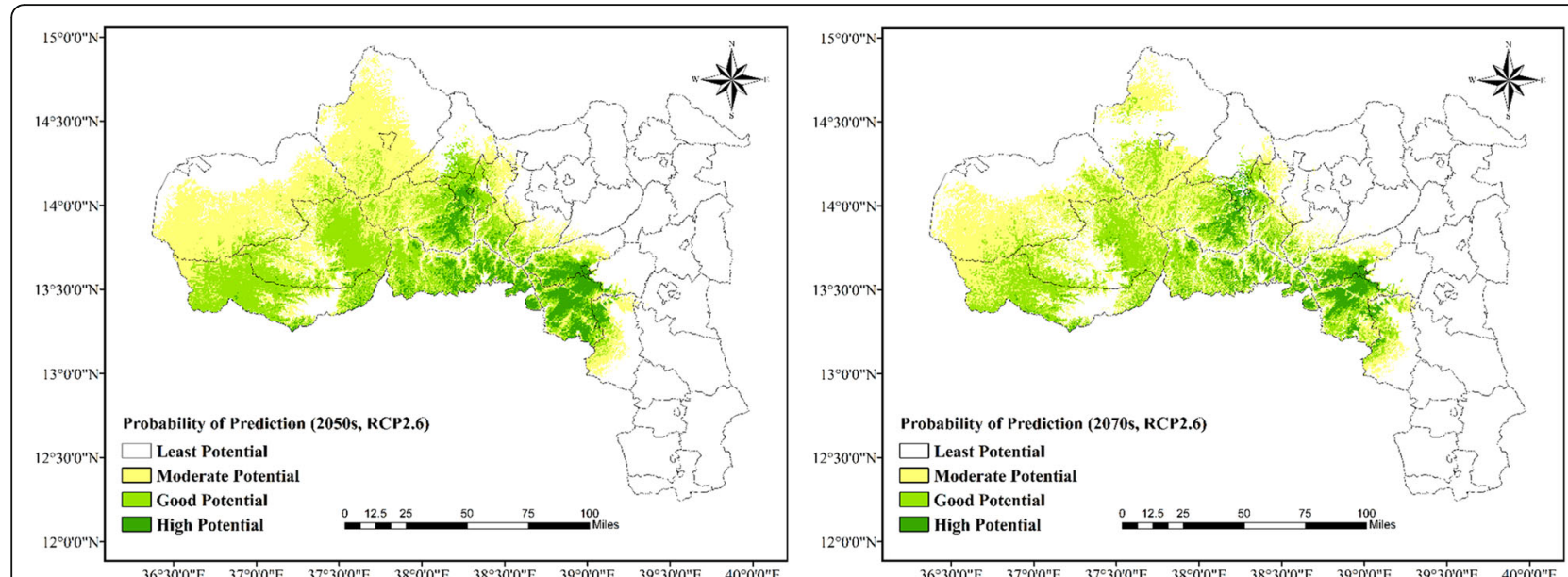

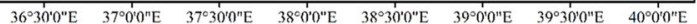

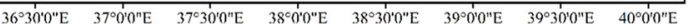
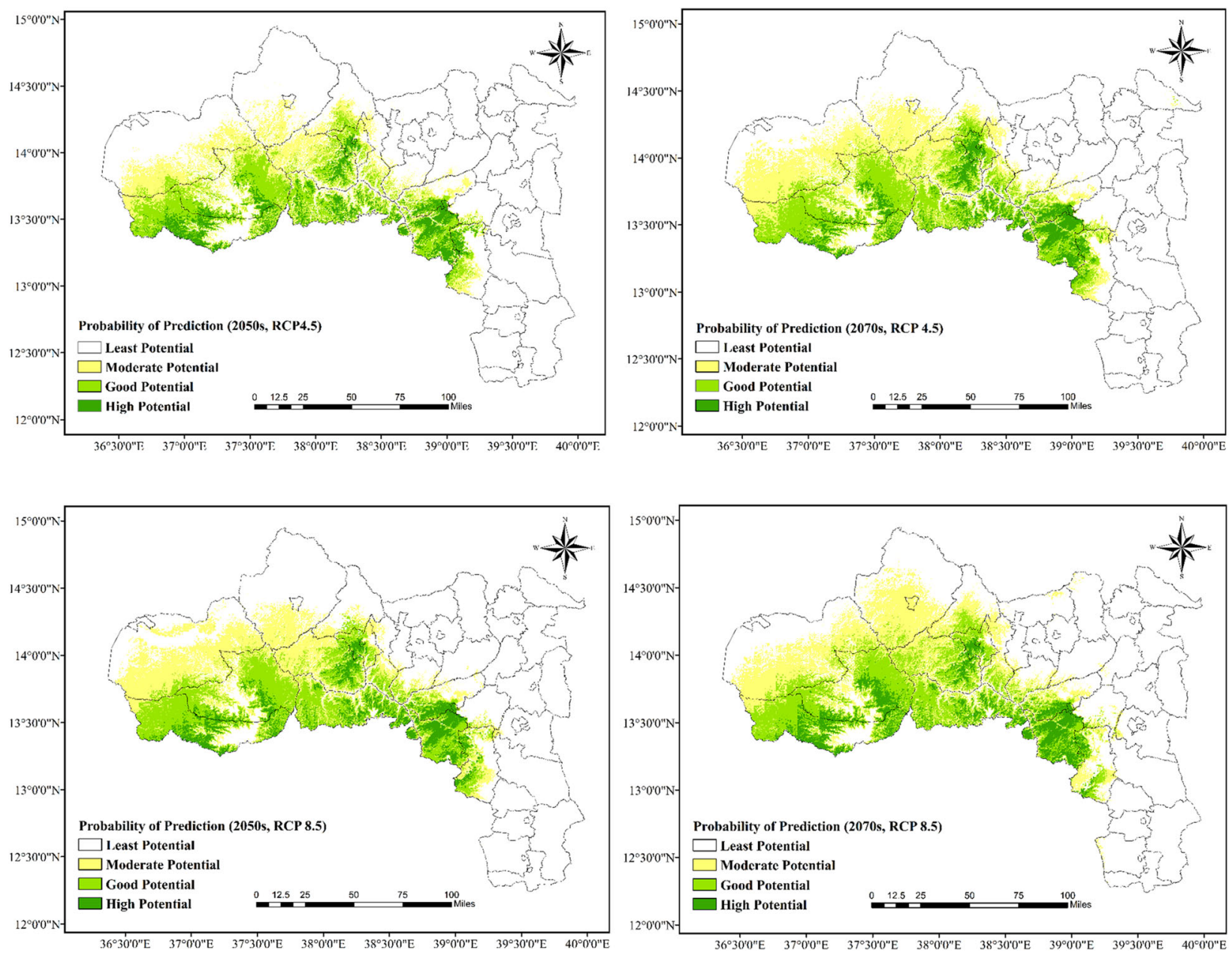

Fig. 6 Suitable habitat for O. abyssinica 2050s RCP 2.6, RCP 4.5, RCP 8.5 and 2070s RCP 2.6, RCP 4.5, RCP 8.5

used in this model may not adequately clarify the current and future distribution of species. Nonclimatic factors such as biotic interaction, species dispersal mode and ability, potential land-cover changes, and other anthropogenic factors have not been used in the model that might influence the results, and this is a limitation of the research. Although these species distribution models have many assumptions and uncertainties, such species distribution models still remain a critical data source for future suitability 
Table 5 Predicted potential distribution areas (ha) for O. abyssinica under mid-century (2050) climatic conditions

\begin{tabular}{|c|c|c|c|c|c|c|c|c|c|c|c|}
\hline \multirow[t]{2}{*}{ Number } & \multirow[t]{2}{*}{ Wereda } & \multirow[t]{2}{*}{ Zone name } & \multicolumn{3}{|c|}{ RCP 2.62050} & \multicolumn{3}{|c|}{ RCP 4.52050} & \multicolumn{3}{|c|}{ RCP 8.52050} \\
\hline & & & Moderate & Good & High & Moderate & Good & High & Moderate & Good & High \\
\hline 1 & Abiy Adi Town & Central & 113.04 & 239.31 & 2106.54 & 190.08 & 390.69 & 1808.64 & 164.70 & 232.02 & 2014.74 \\
\hline 2 & Asgede Tsimbla & $\begin{array}{l}\text { North } \\
\text { Western }\end{array}$ & $\begin{array}{l}153 \\
098.73\end{array}$ & $33,914.43$ & 1205.28 & $\begin{array}{l}121 \\
047.48\end{array}$ & $52,065.99$ & $21,710.52$ & $\begin{array}{l}125 \\
224.65\end{array}$ & $70,094.97$ & $28,562.04$ \\
\hline 3 & Degua Temben & South Eastern & 1760.94 & 1209.78 & 1018.89 & 8480.79 & 3379.05 & 1027.44 & 8738.82 & 3106.80 & 972.27 \\
\hline 4 & Enderta & South Eastern & - & - & - & 806.85 & 88.83 & - & 2750.13 & 271.89 & - \\
\hline 5 & Hintalo Wejirat & South Eastern & - & - & - & 218.79 & - & - & 1060.02 & 46.53 & - \\
\hline 6 & Shire E/slasie & $\begin{array}{l}\text { North } \\
\text { Western }\end{array}$ & 38.16 & - & - & 126.63 & 468.99 & 827.01 & 125.01 & 425.25 & 908.64 \\
\hline 7 & Kafta Humera & Western & $\begin{array}{l}213 \\
494.85\end{array}$ & $26,362.53$ & 161.55 & $\begin{array}{l}193 \\
515.03\end{array}$ & $19,947.06$ & 26.19 & $\begin{array}{l}337 \\
298.58\end{array}$ & $30,420.72$ & 11.25 \\
\hline 8 & Kola Temben & Central & $24,499.71$ & $22,668.21$ & $25,020.99$ & $36,023.49$ & $18,737.19$ & $16,313.49$ & $32,066.82$ & $21,380.94$ & $24,939.18$ \\
\hline 9 & Laelay Adiyabo & $\begin{array}{l}\text { North } \\
\text { Western }\end{array}$ & $34,040.61$ & 827.19 & 0.54 & $39,772.17$ & $15,071.94$ & 633.69 & $28,703.61$ & 9823.50 & 12.87 \\
\hline 10 & Medebay Zana & $\begin{array}{l}\text { North } \\
\text { Western }\end{array}$ & $30,996.72$ & $10,459.08$ & 894.78 & $32,846.76$ & 9948.60 & 507.51 & $33,153.12$ & $16,629.66$ & 1132.02 \\
\hline 11 & Mereb Leke & Central & 536.85 & - & - & 298.71 & - & - & - & - & - \\
\hline 12 & Naeder Adet & Central & $22,076.91$ & 8422.02 & 1431.18 & $16,612.83$ & 3846.51 & 204.39 & $23,180.94$ & 9462.60 & 1169.10 \\
\hline 13 & Saharti Samre & South Eastern & 3328.56 & 6266.16 & 3396.87 & $40,876.74$ & $32,882.76$ & $17,304.03$ & $54,186.21$ & $37,633.23$ & $15,473.07$ \\
\hline 14 & Setit Humera & Western & - & - & - & - & - & - & 109.26 & - & - \\
\hline 15 & Sheraro Town & $\begin{array}{l}\text { North } \\
\text { Western }\end{array}$ & 4853.88 & 120.33 & - & 1677.06 & - & - & 710.46 & - & - \\
\hline 16 & Tahtay Adiyabo & $\begin{array}{l}\text { North } \\
\text { Western }\end{array}$ & $\begin{array}{l}167 \\
333.67\end{array}$ & 9154.44 & 5.94 & $56,276.10$ & 741.78 & - & $\begin{array}{l}102 \\
337.11\end{array}$ & 854.37 & - \\
\hline 17 & Tahtay Koraro & $\begin{array}{l}\text { North } \\
\text { Western }\end{array}$ & $15,425.01$ & 1140.57 & 30.42 & $21,951.99$ & $20,994.21$ & 9579.33 & $20,795.76$ & $24,345.54$ & $11,317.50$ \\
\hline 18 & $\begin{array}{l}\text { Tahtay } \\
\text { Maychew }\end{array}$ & Central & 3787.74 & 228.24 & 2.07 & 2128.59 & 55.89 & - & 2986.56 & 9.09 & - \\
\hline 19 & $\begin{array}{l}\text { Tanqua } \\
\text { Abergele }\end{array}$ & Central & $35,066.88$ & $34,704.36$ & $37,769.13$ & $20,353.50$ & $47,425.41$ & $66,125.70$ & $14,743.62$ & $59,302.62$ & $65,454.39$ \\
\hline 20 & Tsegede & Western & $77,785.29$ & $\begin{array}{l}142 \\
710.84\end{array}$ & $38,023.65$ & $61,549.29$ & $\begin{array}{l}134 \\
058.51\end{array}$ & $72,459.90$ & $44,726.49$ & $\begin{array}{l}169 \\
935.57\end{array}$ & $62,889.93$ \\
\hline 21 & Tselemti & $\begin{array}{l}\text { North } \\
\text { Western }\end{array}$ & $70,210.17$ & $\begin{array}{l}106 \\
794.27\end{array}$ & $48,831.75$ & $68,623.11$ & $94,649.58$ & $57,604.86$ & $58,702.59$ & $\begin{array}{l}126 \\
758.70\end{array}$ & $55,584.54$ \\
\hline 22 & Welkait & Western & $\begin{array}{l}135 \\
116.46\end{array}$ & $\begin{array}{l}133 \\
982.82\end{array}$ & $14,791.41$ & $\begin{array}{l}107 \\
497.89\end{array}$ & $\begin{array}{l}159 \\
727.05\end{array}$ & $34,056.27$ & $\begin{array}{l}102 \\
131.64\end{array}$ & $\begin{array}{l}190 \\
745.01\end{array}$ & $34,532.82$ \\
\hline 23 & Werei Leke & Central & 456.93 & 5.13 & 0.09 & 2705.85 & 23.49 & - & 3514.95 & 13.32 & - \\
\hline \multicolumn{3}{|l|}{ Total area } & $\begin{array}{l}994 \\
021.11\end{array}$ & $\begin{array}{l}539 \\
209.71\end{array}$ & $\begin{array}{l}174 \\
691.08\end{array}$ & $\begin{array}{l}833 \\
579.73\end{array}$ & $\begin{array}{l}614 \\
503.53\end{array}$ & $\begin{array}{l}300 \\
188.97\end{array}$ & $\begin{array}{l}997 \\
411.05\end{array}$ & $\begin{array}{l}771 \\
492.33\end{array}$ & $\begin{array}{l}304 \\
974.36\end{array}$ \\
\hline
\end{tabular}

prediction in order to evaluate scientific adaptation strategies for offsetting future warming impact on biota at species, community, and ecosystem levels (Wiens et al. 2009, Ackerly et al. 2010).

\section{Conclusion}

This study efficiently modeled Oxytenanthera abyssinica's habitat suitability for current and future climate change scenarios. The spatial resolution also made it much easier for the model to predict suitable habitats accurately. This research suggests that Oxytenanthera abyssinica's habitat suitability will increase for 2050 and 2070 under the moderate climate change scenario. In order to protect shifting from their niche, this study suggests incorporating future climate scenario into current restoration and conservation policies to protect ecologically sensitive species in the current habitat. In addition, the 
Table 6 Predicted potential distribution areas (ha) for O. abyssinica under end century (2070) climatic conditions

\begin{tabular}{|c|c|c|c|c|c|c|c|c|c|c|c|}
\hline \multirow[t]{2}{*}{ Number } & \multirow[t]{2}{*}{ Wereda } & \multirow[t]{2}{*}{ Zone name } & \multicolumn{3}{|c|}{ RCP 2.62070} & \multicolumn{3}{|c|}{ RCP 4.52070} & \multicolumn{3}{|c|}{ RCP 8.52070} \\
\hline & & & Moderate & Good & High & Moderate & Good & High & Moderate & Good & High \\
\hline 1 & Abiy Adi Town & Central & 88.65 & 154.53 & 2227.05 & 138.51 & 237.24 & 2040.30 & 171.90 & 378.72 & 1863.18 \\
\hline 2 & Ahferom & Central & - & - & - & - & - & - & 1773.72 & - & - \\
\hline 3 & Emba Alaje & Southern & - & - & - & - & - & - & 197.55 & - & - \\
\hline 4 & Raya Alamata & Southern & - & - & - & - & - & - & 134.73 & 0.18 & - \\
\hline 5 & Asgede Tsimbla & $\begin{array}{l}\text { North } \\
\text { Western }\end{array}$ & $109,642.50$ & $76,012.83$ & $30,546.90$ & $117,949.59$ & $68,397.12$ & $34,813.08$ & $108,565.29$ & $96,704.64$ & $24,733.08$ \\
\hline 6 & Degua Temben & $\begin{array}{l}\text { South } \\
\text { Eastern }\end{array}$ & 5350.23 & 2478.60 & 2553.57 & 8243.28 & 3870.63 & 1616.40 & $11,704.41$ & 4199.85 & 1268.10 \\
\hline 7 & Enderta & $\begin{array}{l}\text { South } \\
\text { Eastern }\end{array}$ & 873.81 & 5.31 & - & 2174.94 & 50.31 & - & 4029.39 & 481.50 & - \\
\hline 8 & Erob & Eastern & - & - & - & 1282.23 & 224.73 & 17.28 & - & - & - \\
\hline 9 & Hawzen & Eastern & - & - & - & - & - & - & 1071.81 & - & - \\
\hline 10 & Hintalo Wejirat & $\begin{array}{l}\text { South } \\
\text { Eastern }\end{array}$ & 478.44 & 2.07 & - & 637.92 & 13.14 & - & 2064.15 & 196.47 & - \\
\hline 11 & Shire E/slasie & $\begin{array}{l}\text { North } \\
\text { Western }\end{array}$ & 89.19 & 207.00 & 648.09 & 68.22 & 149.13 & 1245.96 & 96.75 & 442.62 & 922.05 \\
\hline 12 & Kafta Humera & Western & $294,316.74$ & $44,757.99$ & 54.90 & $316,111.05$ & $27,410.76$ & 101.88 & $295,633.98$ & $50,295.24$ & 191.61 \\
\hline 13 & Kola Temben & Central & $29,489.85$ & $22,450.41$ & $27,532.62$ & $34,826.49$ & $22,267.89$ & $23,066.37$ & $36,557.82$ & $23,453.73$ & $21,186.36$ \\
\hline 14 & Laelay Adiyabo & $\begin{array}{l}\text { North } \\
\text { Western }\end{array}$ & $22,199.76$ & 8883.27 & 687.78 & $44,139.33$ & $20,131.02$ & 1831.95 & $64,028.70$ & $25,018.83$ & 261.81 \\
\hline 15 & $\begin{array}{l}\text { Laelay } \\
\text { Maychew }\end{array}$ & Central & 221.49 & - & - & - & - & - & - & - & - \\
\hline 16 & Medebay Zana & $\begin{array}{l}\text { North } \\
\text { Western }\end{array}$ & $42,060.24$ & $22,767.66$ & 2800.17 & $39,885.48$ & $18,405.27$ & 2815.29 & $48,081.87$ & $17,315.19$ & 994.77 \\
\hline 17 & Mereb Leke & Central & 478.26 & - & - & & & & 3643.83 & - & - \\
\hline 18 & Naeder Adet & Central & $23,630.58$ & 8188.20 & 1766.97 & $23,531.85$ & 9384.66 & 1421.10 & $26,689.32$ & 9031.50 & 1040.04 \\
\hline 19 & Ofla & Southern & - & - & - & - & - & - & 3029.04 & 64.26 & - \\
\hline 20 & Saharti Samre & $\begin{array}{l}\text { South } \\
\text { Eastern }\end{array}$ & $44,580.42$ & $23,725.35$ & 7872.66 & $46,426.14$ & $42,991.47$ & $16,013.34$ & $54,043.20$ & $29,079.81$ & $14,324.94$ \\
\hline 21 & Sheraro Town & $\begin{array}{l}\text { North } \\
\text { Western }\end{array}$ & 2105.46 & 351.81 & - & 3194.91 & - & - & 6457.77 & - & - \\
\hline 22 & Tahtay Adiyabo & $\begin{array}{l}\text { North } \\
\text { Western }\end{array}$ & $145,803.42$ & $47,532.33$ & 72.00 & $127,992.51$ & 2142.54 & - & $213,054.57$ & $10,017.72$ & 0.27 \\
\hline 23 & Tahtay Koraro & $\begin{array}{l}\text { North } \\
\text { Western }\end{array}$ & $13,286.79$ & $22,361.94$ & $13,938.66$ & $14,744.16$ & $22,447.44$ & $20,742.30$ & $17,640.27$ & $27,776.34$ & $13,290.57$ \\
\hline 24 & $\begin{array}{l}\text { Tahtay } \\
\text { Maychew }\end{array}$ & Central & 5600.79 & 873.36 & 1.08 & 4182.12 & 234.63 & - & 4142.16 & 169.20 & - \\
\hline 25 & $\begin{array}{l}\text { Tanqua } \\
\text { Abergele }\end{array}$ & Central & $35,247.24$ & $42,407.55$ & $50,317.92$ & $13,671.18$ & $53,093.97$ & $71,920.17$ & $11,258.73$ & $44,586.54$ & $84,779.19$ \\
\hline 26 & Tsegede & Western & $111,551.49$ & $\begin{array}{l}138 \\
778.74\end{array}$ & 7535.07 & $75,103.29$ & $\begin{array}{l}161 \\
790.03\end{array}$ & $41,992.83$ & $46,519.29$ & $\begin{array}{l}154 \\
742.13\end{array}$ & $77,900.58$ \\
\hline 27 & Tselemti & $\begin{array}{l}\text { North } \\
\text { Western }\end{array}$ & $74,550.51$ & $\begin{array}{l}100 \\
692.63\end{array}$ & $45,239.13$ & $62,196.57$ & $\begin{array}{l}113 \\
990.85\end{array}$ & $57,201.03$ & $61,676.91$ & $\begin{array}{l}126 \\
238.41\end{array}$ & $52,597.26$ \\
\hline 28 & Welkait & Western & $126,173.88$ & $\begin{array}{l}162 \\
407.70\end{array}$ & 6092.82 & $109,423.80$ & $\begin{array}{l}189 \\
419.13\end{array}$ & $37,986.75$ & $86,657.04$ & $\begin{array}{l}181 \\
556.73\end{array}$ & $68,622.93$ \\
\hline \multirow[t]{2}{*}{29} & Werei Leke & Central & 1679.58 & 60.93 & - & 4479.21 & 63.09 & 0.36 & 5989.86 & 141.84 & 3.33 \\
\hline & Total area & & $\begin{array}{l}1,089 \\
499.32\end{array}$ & $\begin{array}{l}725 \\
100.21\end{array}$ & $\begin{array}{l}199 \\
887.39\end{array}$ & $\begin{array}{l}1,050 \\
402.78\end{array}$ & $\begin{array}{l}756 \\
715.05\end{array}$ & $\begin{array}{l}314 \\
826.39\end{array}$ & $\begin{array}{l}1,114 \\
914.06\end{array}$ & $\begin{array}{l}801 \\
891.45\end{array}$ & $\begin{array}{l}363 \\
980.07\end{array}$ \\
\hline
\end{tabular}


Table 7 Predicted suitable areas for 0 . abyssinica under current and future climatic conditions

\begin{tabular}{llllll}
\hline Category & & Least potential $(<0.2)$ & Moderate potential (0.2-0.4) & Good potential (0.4-0.6) & High potential $(>0.6)$ \\
\hline Current & Area (ha) & $4,040,197.65$ & $537,942.96$ & $722,737.44$ & $136,804.05$ \\
& Cover (\%) & 74.30 & 9.89 & 13.29 & 2.52 \\
RCP 2.6 2050 & Area (ha) & $3,729,556.17$ & $994,087.98$ & $539,276.31$ & $174,761.64$ \\
& Cover (\%) & 68.59 & 18.28 & 9.92 & 3.21 \\
RCP 2.6 2070 & Area (ha) & $3,422,752.29$ & $1,089,782.19$ & $725,219.19$ & $199,928.43$ \\
& Cover (\%) & 62.95 & 20.04 & 13.34 & 3.68 \\
RCP 4.5 2050 & Area (ha) & $3,689,079.57$ & $833,703.48$ & $614,636.55$ & $300,262.50$ \\
& Cover (\%) & 67.84 & 15.33 & 11.30 & 5.52 \\
RCP 4.5 2070 & Area (ha) & $3,315,410.10$ & $1,050,499.71$ & $756,836.28$ & $314,936.01$ \\
& Cover (\%) & 60.97 & 19.32 & 13.92 & 5.79 \\
RCP 8.5 2050 & Area (ha) & $3,363,330.24$ & $997,675.65$ & $771,619.68$ & $305,056.53$ \\
& Cover (\%) & 61.85 & 18.35 & 14.19 & 5.61 \\
RCP 8.5 2070 & Area (ha) & $3,156,399.090$ & $1,115,199.000$ & $802,022.220$ & $364,061.790$ \\
& Cover (\%) & 58.047 & 20.509 & 14.749 & 6.695 \\
\hline
\end{tabular}

findings of this research may contribute to a better understanding of the environmental factors affecting Oxytenanthera abyssinica's current distributions. However, the validation of this model requires further field research on the distribution of Oxytenanthera abysinica.

\section{Acknowledgements}

The authors acknowledge the financial support from Tigray Agricultural Research Institute (Mekelle Agricultural Research Center).

\section{Authors' contributions}

YG, SA, EM, and GE designed the study. YG and SA analyzed the data. YG, $S A$, and EM wrote the manuscript. All authors read and approved the final manuscript.

\section{Funding}

The funders had no role in the study design, data collection and analysis, decision to publish, or preparation of the manuscript.

\section{Availability of data and materials}

Please contact the author for data requests.

\section{Ethics approval and consent to participate}

Not applicable

\section{Consent for publication}

Not applicable

\section{Competing interests}

The authors declare that they have no competing interests.

\section{Author details}

${ }^{1}$ Mekelle Agricultural Research Center (MARC), Tigray Agricultural Research Institute (TARI), P.O. Box 256, Tigray, Ethiopia. ${ }^{2}$ Mekelle Soil Research Center (MSRC), Tigray Agricultural Research Institute (TARI), P.O. Box 1070, Tigray, Ethiopia. ${ }^{3}$ Humera Agricultural Research Center (HuARC), Tigray Agricultural Research Institute (TARI), P.O. Box 62, Tigray, Ethiopia. ${ }^{4}$ Abergele Agricultural Research Center (AARC), Tigray Agricultural Research Institute (TARI), P.O. Box 44, Tigray, Ethiopia. ${ }^{5}$ Shire-Mytsebri Agricultural Research Center (SmARC), Tigray Agricultural Research Institute (TARI), P.O. Box 241, Tigray, Ethiopia.
Received: 25 September 2019 Accepted: 20 December 2019

Published online: 03 February 2020

\section{References}

Ackerly D, Loarie S, Cornwell W, Weiss S, Hamilton H, Branciforte R, Kraft N (2010) The geography of climate change: implications for conservation biogeography. Diversity and Distributions 16:476-487

Baghel L, Gupta A, Verma R, Totey N (1998) Socio-economic and bamboo consumption pattern in villages around Jebelbur and Mandla, Mahdhya Pradesh: a case study. Journal of Tropical Forestry 14:252-261

Banik RL (1985) Techniques of bamboo propagation with special reference to pre-rooted and pre-rhizomed branch cuttings and tissue culture. Recent Research on Bamboos, pp 160-169

Bein E, Habte B, Jaber A, Birnie A, Tengnäs B (1996) Useful trees and shrubs in Eritrea: identification, propagation and management for agricultural and pastoral communities. Technical Handbook 12:422

Bekele-Tesemma A, Tengnäs B (2007) Useful trees and shrubs of Ethiopia: identification, propagation, and management for 17 agroclimatic zones. RELMA in ICRAF Project, World Agroforestry Centre, Eastern Africa Region

Bystriakova N, Kapos V, Lysenko I (2004) Bamboo biodiversity: Africa. Madagascar and the Americas, UNEP/Earthprint

Cao M, Prince SD, Small J, Goetz SJ (2004) Remotely sensed interannual variations and trends in terrestrial net primary productivity 1981-2000. Ecosystems 7: 233-242

Cheaib A, Badeau V, Boe J, Chuine I, Delire C, Dufrêne E, François C, Gritti ES, Legay M, Pagé C (2012) Climate change impacts on tree ranges: model intercomparison facilitates understanding and quantification of uncertainty. Ecology Letters 15:533-544

Christanty L, Kimmins J, Mailly D (1997) 'Without bamboo, the land dies': a conceptual model of the biogeochemical role of bamboo in an Indonesian agroforestry system. Forest Ecology and Management 91:83-91

Elith JH, Graham CP, Anderson R, Dudík M, Ferrier S, Guisan AJ, Hijmans R, Huettmann FR, Leathwick J, Lehmann A (2006) Novel methods improve prediction of species' distributions from occurrence data. Ecography 29:129151

Elith J (2000) Quantitative methods for modeling species habitat: comparative performance and an application to Australian plants. Quantitative methods for conservation biology. Springer

Elith J, Kearney M, Phillips S (2010) The art of modelling range-shifting species. Methods in Ecology and Evolution 1:330-342

Embaye K (2000) The indigenous bamboo forests of Ethiopia: an overview. Ambio 29:518-522

Embaye K (2003) Ecological aspects and resource management of bamboo forests in Ethiopia. Doctoral thesis. Swedish University of Agricultural Sciences, Uppsara 
Fielding AH, Bell JF (1997) A review of methods for the assessment of prediction errors in conservation presence/absence models. Environmental Conservation 24:38-49

Fourcade Y, Engler JO, Rödder D, Secondi J (2014) Mapping species distributions with MAXENT using a geographically biased sample of presence data: a performance assessment of methods for correcting sampling bias. PLoS One 9:e97122

Gebrewahid Y, Teka K, Gebre-Egziabhier T-B, Tewolde-Berhan S, Birhane E, Eyasu G, Meresa E (2019) Dispersed trees on smallholder farms enhance soil fertility in semi-arid Ethiopia. Ecological Processes 8:38

Hamann A, Wang T (2006) Potential effects of climate change on ecosystem and tree species distribution in British Columbia. Ecology 87:2773-2786

Hijmans RJ, Cameron SE, Parra JL, Jones PG, Jarvis A (2005) Very high resolution interpolated climate surfaces for global land areas. International Journal of Climatology 25:1965-1978

Iverson LR, Mckenzie D (2013) Tree-species range shifts in a changing climate: detecting, modeling, assisting. Landscape Ecology 28:879-889

Khanum R, Mumtaz A, Kumar S (2013) Predicting impacts of climate change on medicinal asclepiads of Pakistan using Maxent modeling. Acta Oecologica 49:23-31

Kigomo B (1988) Distribution, cultivation and research status of bamboo in Eastern Africa. Kenya Forestry Research Institute, Nairobi, Kenya

Lamsal P, Kumar L, Atreya K, Pant KP (2017) Vulnerability and impacts of climate change on forest and freshwater wetland ecosystems in Nepal: a review. Ambio 46:915-930

Martín-López B, Palomo I, García-Llorente M, Iniesta-Arandia I, Castro AJ, del Amo DG, Gómez-Baggethun E, Montes C (2017) Delineating boundaries of socialecological systems for landscape planning: a comprehensive spatial approach. Land Use Policy 66:90-104

Ohrnberger D (1999) The bamboos of the world: annotated nomenclature and literature of the species and the higher and lower taxa. Elsevier, Amsterdam

Pearce J, Ferrier S (2000) An evaluation of alternative algorithms for fitting species distribution models using logistic regression. Ecological Modelling 128:127-147

Perez MR, Maogong Z, Belcher B, Chen X, Maoyi F, Jinzhong X (1999) The role of bamboo plantations in rural development: the case of Anji County, Zhejiang, China. World Development 27:101-114

Phillips S (1995) Poaceae (Gramineae). In: Hedberg I, Edwards S (eds) Flora of Ethiopia and Eritrea, vol 7. Uppsala, Sweden, pp 3-6

Phillips S (2006) A brief tutorial on Maxent. AT\&T Research. Retrieved March 2019 from American Museum of Natural History Website

Shanmughavel P, Francis K (1995) Studies on the growth of Bambusa bambos at Kallipatti, Tamilnadu, BIC. India Bulletin 3:46-48

Songer M, Delion M, Biggs A, Huang Q (2012) Modeling impacts of climate change on giant panda habitat. International Journal of Ecology 2012: https://doi.org/10.1155/2012/108752

Stohlgren TJ, Jarnevich CS, Esaias WE, Morisette JT (2011) Bounding species distribution models. Current Zoology 57:642-647

Swets JA (1988) Measuring the accuracy of diagnostic systems. Science 240 $1285-1293$

UNIDO. 2009. Bamboo Cultivation Manual. Guidelines for cultivating Ethiopian lowland bamboo, Eastern Africa Bamboo Project, United Nations Industrial Development Organization (UNIDO). [Online]. Available: unido.org/sites/default/ files/2010-01/Guidelines_for_cultivating_Ethiopian_lowland_bamboo_0.pdf

Virapongse A, Brooks S, Metcalf EC, Zedalis M, Gosz J, Kliskey A, Alessa L (2016) A social-ecological systems approach for environmental management. Journal of Environmental Management 178:83-91

Wang L, Yang J, Zheng Y, Tang G (2011) Modelling the geographic distribution of Malus baccata. Journal of Beijing Forestry University 33:70-74

Wang R, Li Q, He S, Liu Y, Wang M, Jiang G (2018) Modeling and mapping the current and future distribution of Pseudomonas syringae pv. actinidiae under climate change in China. PLoS One 13:e0192153

Wiens JA, Stralberg D, Jongsomjit D, Howell CA, Snyder MA (2009) Niches, models, and climate change: assessing the assumptions and uncertainties. Proceedings of the National Academy of Sciences of the United States of America 106:19729-19736

Xu M, Peng F, You Q, Guo J, Tian X, Xue X, Liu M (2015) Year-round warming and autumnal clipping lead to downward transport of root biomass, carbon and total nitrogen in soil of an alpine meadow. Environmental and Experimental Botany 109:54-62
Xu M, Xue X (2013) Analysis on the effects of climate warming on growth and phenology of alpine plants. Journal of Arid Land Resources and Environment 27:137-141

Yang X-Q, Kushwaha S, Saran S, Xu J, Roy P (2013) Maxent modeling for predicting the potential distribution of medicinal plant, Justicia adhatoda $\mathrm{L}$. in Lesser Himalayan foothills. Ecological Engineering 51:83-87

Yuming Y, Kanglin W, Shengji P, Jiming H (2004) Bamboo diversity and traditional uses in Yunnan, China. Mountain Research and Development 24 157-166

Zhong L, Ma Y, Salama MS, Su Z (2010) Assessment of vegetation dynamics and their response to variations in precipitation and temperature in the Tibetan Plateau. Climatic Change 103:519-535

\section{Publisher's Note}

Springer Nature remains neutral with regard to jurisdictional claims in published maps and institutional affiliations.

\section{Submit your manuscript to a SpringerOpen ${ }^{\circ}$ journal and benefit from:}

- Convenient online submission

- Rigorous peer review

- Open access: articles freely available online

- High visibility within the field

- Retaining the copyright to your article

Submit your next manuscript at $\boldsymbol{\nabla}$ springeropen.com 